\title{
CHINA \\ Debates the Future Security Environment
}

\section{MICHAEL PILLSBURY}

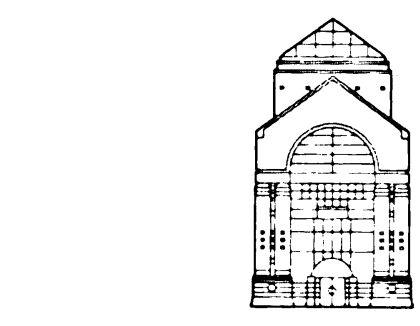

NATIONAL DEFENSE UNIVERSITY PRESS WASHINGTON, D.C. 2000 